Journal homepage: https:/ / ejournal.imperiuminstitute.org/ index.php/ JMSAB

\title{
Penggunaan metode decision tree pada PT. HIS JMSAB Tour \& Travel untuk pembukaan cabang baru
}

\section{Sofiyatun}

Sekolah Tinggi Ilmu Ekonomi Bisnis Indonesia, Jakarta

\section{Haryadi Sarjono}

Binus Business School, Binus University, Jakarta
Paper type

Techincal paper
Keywords: promotion, Forecasting MAD, MSE, QM For Windows, Decision Tree Decomposition Centered Moving Average, Multiplicative Average All and Multiplicative Decomposition Centered Moving Average. This research is supported bya QM For Windows application. The results of this study indicate that the Addictive Decomposition Centered Moving Average method is the best method because it has the smallest MAD and MSE value of 104.76 and 22.897,57 with the results of sales forecasting in the next period which is 1371. This study also uses the Decision Tree method for opening decision new branch, the results obtained are the opening of new branches in the city of Bekasi with an expected value of Rp 280,560,000

\begin{abstract}
Abstrak
Tujuan dari penelitian ini adalah untuk mengetahui peramalan penjualan tiket pesawat pada PT. HIS Tour \& Travel Cabang MM 2100 Cibitung. Metode penelitian ini menggunakan forecasting dengan 7 metode yaitu Exponential Smoothing, Moving Average, Trend Projection, Addictive Decomposition Average All, Addictive Decomposition Centered Moving Average, Multiplicative Average All Dan Multiplicative Decomposition Centered Moving Average. Hasil penelitian ini menunjukkan bahwa metode Addictive Decomposition Centered Moving Average adalah metode terbaik karena memiliki nilai MAD dan MSE terkecil yaitu 104,76 dan 22.897,57 dengan hasil peramalan penjualan pada periode selanjutnya yaitu 1371. Penelitian ini juga menggunakan metode decision tree untuk pengambilan keputusan pembukaan cabang baru, hasil yang didapatkan adalah pembukaan cabang baru di Kota Bekasi dengan nilai harapan Rp 280.560.000
\end{abstract}

*Email korespondensi: haryadi_s@binus.edu

Pedoman Sitasi: Sofiayun \& Haryadi Sarjono. (2019). Penggunaan metode decision tree pada PT. AIS tour \& travel untuk pembukaan cabang baru. Jurnal Manajemen Strategi dan Aplikasi Bisnis, 2(1), 81 - 92
Received: 25 Feb 2019

Accepted: 25 Apr 2019

Online: 30 Apr 2019

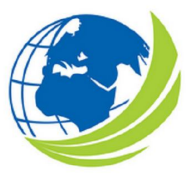

Jurnal Manajemen Strategi dan Aplikasi Bisnis, Vol 2, No.1, April 2019, pp. 81 - 92 eISSN2655-237X 


\section{PENDAHULUAN}

Pariwisata dapat diartikan sebagai suatu perjalanan yang dilakukan untuk rekreasi atau liburan. Zaman modern seperti sekarang ini berwisata bukan lagi menjadi kebutuhan mewah. Pariwisata seolah menjadi trend baru untuk menghabiskan waktu luang. Pariwisata juga merupakan salah satu mesin penggerak perekonimian dunia yang terbukti dapat memberikan kontribusi pada kemakmuran sebuah negara. Pembangunan pariwisata mampu menggairahkan aktivitas bisnis untuk menghasilkan manfaat sosial, budaya sekaligus ekonomi yang signifikan bagi suatu negara. Pariwisata yang direncanakan dengan baik mestinya dapat memberikan manfaat pada sebuah destinasi. Keberhasilan pariwisata dapat dilihat dari penerimaan pemerintah dari sektor pariwisata yang dapat mendorong sektor lainnya untuk berkembang (Utama,2017).

Tabel 1. Penyumbang Devisa terbesar di Indonesia

\begin{tabular}{c|l|c}
\hline 1 & Devisa Hasil Ekspor Kelapa Sawit & Rp 239 triliun \\
\hline 2 & Jasa Pariwisata (Turis Asing) & Rp 190 triliun \\
\hline 3 & Ekspor Migas & Rp 170 triliun \\
\hline 4 & Eskpor Tekstil & Rp 159 triliun \\
\hline 5 & Ekspor Batubara & Rp 150 triliun \\
\hline 6 & Jasa TKI & Rp 140 triliun \\
\hline 7 & Ekspor Elektronik & Rp 80 triliun \\
\hline 8 & Ekspor Hasil Kayu Hutan & Rp 70 triliun \\
\hline 9 & Ekspor Karet & Rp 65 triliun \\
\hline 10 & Ekspor Sepatu dan Sandal & Rp 60 triliun \\
\hline
\end{tabular}

Sumber: BPS dan Kementerian Perindustrian (2017)

Melihat tabel di atas dapat disimpulkan bahwa sektor pariwata memberikan pemasukan negara yang cukup besar, bahkan mampu mengalahkan sektor migas yang tahun-tahun sebelumnya selalu berada di peringkat kedua.

Transportasi adalah berpindahnya manusia atau barang dari satu menuju tempat lainnya dengan menggunakan sebuah kendaraan yang digerakkan oleh manusia ataupun mesin. Transportasi dibagi menjadi 3 yaitu; transportasi darat, laut dan udara. Transportasi udara merupakan transportasi yang membutuhkan uang lebih banyak dalam pemakaiannya dibanding dengan alat transportasi lain, selain karena teknologinya yang canggih, transportasi udara merupakan alat transportasi paling cepat dibandingkan dengan alat transportasi lainnya.( Salim,2015).

Sarana yang digunakan dalam pengoperasian transportasi udara seperti pesawat dan helikopter. Pesawat adalah salah satu pilihan terbaik untuk bepergian, karena dapat menjangkau wilayah yang jauh dengan cepat dan praktis. Pada zaman modern seperti ini masyarakat lebih menyukai hal-hal yang praktis dan tidak membuah waktu mereka terlalu banyak. Berikut beberapa alasan mengapa peneliti memilih jasa penjualan tiket pesawat terbang:

Pertama, tingkat mobilitas masyarakat semakin meningkat, mereka lebih mengiginkan bepergian dari satu tempat ke tempat lain dengan mudah, murah, nyaman, aman dan tentunya cepat, ini melahirkan satu sarana transportasi yang mampu menjawab segala keinginan dari masyarakat tersebut, yaitu alat transportasi udara, alat transportasi udara ini relatif lebih cepat dibandingkan alat transportasi lainnya. Ditambah bahwa Indonesia adalah Negara Kepulauan, maka alat transportasi udara sangat dipilih oleh masyarakat Indonesia untuk mengantarkan mereka bepergian ke berbagai pulau di Indonesia. (Atmadjati, 2014). Kedua, Badan Pusat Statistik (BPS) mencatat bahwa peningkatan jumlah penumpang angkutan udara domestik pada April 2017 sebanyak 7,9 juta orang. Jumlah ini menunjukan kenaikan 2,32 persen dibanding Maret 2018 atau bulan sebelumnya (Merdeka.com,2018).

Ketiga, meningkatnya pertumbuhan jumlah penumpang pesawat udara di Indonesia membuat Angkasa Pura II sebagai pengelola 13 bandara di Indonesia untuk berubah, baik dari sisi operasional 
maupun digitalisasi layanannya. (SWA, 2017). Terakhir, setiap tahun jumlah penumpang pesawat udara di Indonesia mengalami kenaikan 12 persen yang diikuti dengan peningkatan jumlah armada pesawat (Tribunnews, 2018)

Tabel 2. Jumlah Penduduk Menurut Status Pekerjaan Tahun 2015

\begin{tabular}{clrrr}
\hline No & Kecamatan & \multicolumn{1}{c}{ Bekerja } & Tidak Bekerja & \multicolumn{1}{c}{ Jumlah } \\
\hline $\mathbf{1}$ & Bekasi Timur & 208.744 & 56.891 & 265.635 \\
$\mathbf{2}$ & Bekasi Barat & 213.812 & 59.642 & 273.454 \\
$\mathbf{3}$ & Bekasi Utara & 250.646 & 70.308 & 320.954 \\
$\mathbf{4}$ & Bekasi Selatan & 155.340 & 42.977 & 198.317 \\
$\mathbf{5}$ & Rawalumbu & 176.326 & 40.885 & 217.211 \\
$\mathbf{6}$ & Medan Satria & 117.245 & 35.192 & 152.437 \\
$\mathbf{7}$ & Bantar Gebang & 72.101 & 24.283 & 96.384 \\
$\mathbf{8}$ & Pondok Gede & 222.271 & 44.455 & 266.726 \\
$\mathbf{9}$ & Jati Asih & 164.739 & 41.195 & 205.934 \\
$\mathbf{1 0}$ & Jati Sampurna & 82.744 & 21.580 & 104.324 \\
$\mathbf{1 1}$ & Mustika Jaya & 124.864 & 36.784 & 161.648 \\
$\mathbf{1 2}$ & Pondok Melati & 96.025 & 25.364 & 121.389 \\
\hline Total & & $\mathbf{1 . 8 8 4 . 8 5 7}$ & $\mathbf{4 9 9 . 5 5 6}$ & $\mathbf{2 . 3 8 4 . 4 1 3}$ \\
\hline \multicolumn{2}{l}{ Sumber: Dinas Kependudukan dan Catatan Sipil Kota Bekasi (2015) }
\end{tabular}

Tabel diatas menampilkan jumlah penduduk bekerja dan tidak bekerja yang beradadi Kota Bekasi, dari tabel tersebut dapat dilihat bahwa penduduk bekasi yang bekerja lebih banyak daripada yang tidak bekerja

Adapun tujuan dari penelitian ini adalah untuk mengetahui mengetahui : (1) seberapa banyak jumlah tiket yang akan terjual pada periode mendatang?; (2) metode peramalan apakah yang harus digunakan supaya peramalan mendapatkan hasil yang efisien dan efektif?; (3) apakah keputusan menambah cabang adalah keputusan yang tepat?; dan (4) daerah mana yang harus dipilih untuk pembukaan cabang baru?

\section{KAJIAN PUSTAKA}

Pengertian Peramalan (forecasting)

Peramalan (forecasting) dapat diartikan sebagai berikut :

1. Menurut Sarjono dalam Sarjono dan Abbas (2017) peramalan adalah memprediksi sesuatu yang akan datang dengan perhitungan data historis.

2. Menurut Hasibuan dalam Sarjono dan Abbas (2017) metode forecasting merupakan suatu cara untuk memperkirakan atau mengestimasi secara kuantitatif maupun kualitatif apa yang akan terjadi di di masa depan berdasarkan data yang relevan pada masa lalu.

3. Menurut Prasetya dan Lukiastuti (2013), peramalan adalah suatu usaha untuk meramalkan keadaan di masa.

Pengertian Pohon Keputusan (Decision Tree)

Pohon keputusan (Decision Tree) dapat diartikan sebagai berikut :

1. Pohon keputusan adalah alat bantu manjemen dalam pembuatan keputusan untuk berbagai pemasalahan yang kompleks dan memerlukan serangkaian pemecahan masalah yang berurutan dalam suatu team kerja yang baik. (Chaniago, 2017).

2. Menurut Kasim dalam Chaniago (2017) pohon keputusan dapat diartikan sebagai model grafik yang menggambarkan urut-urutan suatu putusan dan peristiwa-peristiwa yang terdiri dari situai keputusan yang berangkai. 
3. Menurut Welch dan Comer (2017) pohon keputusan merupakan suatu diagram yang sederhana yang menunjukkan suatu proses merinci untuk merinci masalah kedalam komponen-komponen kemudian dibuatkan alternatif-alternatif pemecahan dan konsekuensi setiap alternatif.

QM For Windows

1. Menurut Sarjono (2014:G-3), Quantitative Method for Windows ialah paket program komputer untuk membantu menyelesaikan persoalan-persoalan metode kuantitatif, manajemen sains, atau riset operasi.

2. Menurut Render (2006) dalam Sarjono dan Abbas (2017), QM For Windows merupakan sebuah paket software untuk teknik kuantitatif yang dikembangkan oleh Profesor Howard Weiss. Software ini berbasiskan menu dan sangat mudah digunakan bahkan oleh pengguna yang tidak memiliki pengalaman komputer.
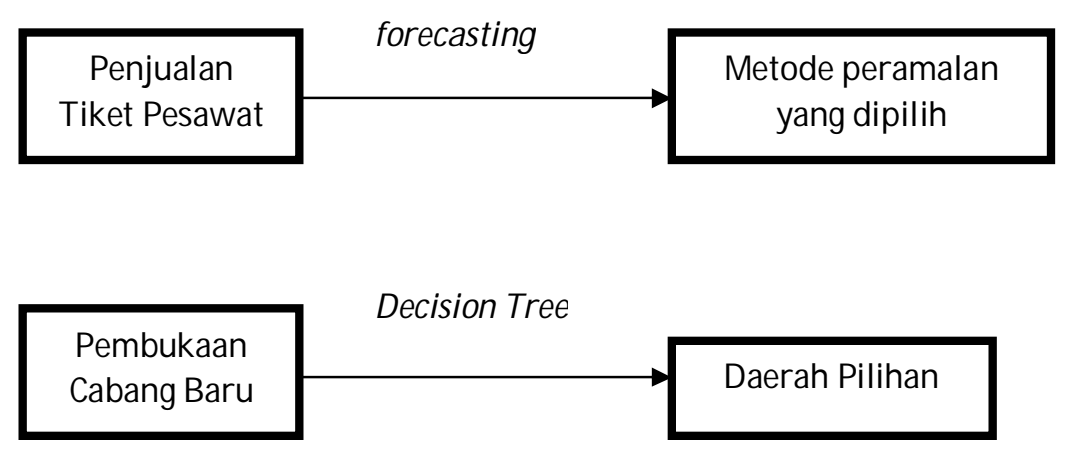

\section{Gambar 1. Kerangka Model}

\section{METODE PENELITIAN}

\section{Data}

Pengumpulan data merupakan langkah penting dala sebuah peelitian, sehingga memerlukan teknik pengumpula data yang tepat supaya menghasilkan data yang sesuai. Tanpa memiliki kemampuan teknik pengumpulan data, penulis akan sulit mendapatan data penelitian yang standar. Menurut Sugiyono dalam Firdaus dan Zamzam (2018:103) teknik pengumpulan data dapat dilakukan dengan obsevation (pengamatan), interview (wawancara), kuesioner ataupun gabungan dari ketiga cara tersebut. Menurut Juanda dalam Firdaus dan Zamzam (2018:102) cara memperoleh data dibagi menjadi 2 yaitu: (1) data Primer, yang dikumpulkan oleh peneliti sendiri baik secara perorangan ataupun organisasi; (2) data Sekunder yang diperoleh dalam bentuk yang sudah jadi berupa publikasi ataupun file digital.

Menurut Sugiyono dalam Firdaus dan Zamzam data sumber sekunder adalah sumber data yang tidak secara lansung memberikan data kepada sumber data, seperti dari dokumentasi. Dalam penelitian ini penulis menggunakan data sekunder sebagai sumber informasi. Data tersebut diperoleh dari data perusahaan yang penulis teliti yaitu PT Harum Indah Sari Tour \& Travel.

Pengukuran (measurement)

Pengukuran variabel ditampilkan pada Tabel berikut ini: 
Jurnal Manajemen Strategi dan Aplikasi Bisnis, 2(1), 81 - 92

Sofiyatun \& Haryadi Sarjono. Penggunaan metode...

Tabel 3. Operasional Variabel Penelitian

\begin{tabular}{|c|c|c|c|}
\hline No & Variabel & Konsep Variabel & Indikator Utama \\
\hline 1 & Peramalan & & Data dari penjualan tiket pesawat periode $2017-2018$ \\
\hline 2 & $\begin{array}{l}\text { Model } \\
\text { Peramalan }\end{array}$ & $\begin{array}{l}\text { Metode peramalan } \\
\text { yang akan diterapkan } \\
\text { pada penelitian di PT } \\
\text { Harum Indah Sari } \\
\text { Tour\&Travel Cabang } \\
\text { MM2100 }\end{array}$ & $\begin{array}{l}\text { Moving average techniques, Exponential Smoothing, } \\
\text { Trend Projection, Decomposition techniques (addictive } \\
\text { decomposition- average all, addictive decomposition- } \\
\text { CMA, multiplicative decomposition-average all, } \\
\text { multiplicative decomposition-CMA), decision tree }\end{array}$ \\
\hline 3 & $\begin{array}{l}\text { Hasil } \\
\text { peramalan }\end{array}$ & $\begin{array}{l}\text { Ukuran akurasi hasil } \\
\text { peramalan }\end{array}$ & MAD dan MSE terkecil untuk Forecasting \\
\hline 4 & $\begin{array}{l}\text { Pohon } \\
\text { Keputusan }\end{array}$ & & Kondisi Politik Ekonomi Setiap Kota \\
\hline 5 & $\begin{array}{l}\text { Kriteria } \\
\text { Keputusan }\end{array}$ & $\begin{array}{l}\text { Kriteria keputusan } \\
\text { yang digunakan untuk } \\
\text { penghitungan masing- } \\
\text { masing kota }\end{array}$ & $\begin{array}{l}\text { Maximax, Maximin, Maximax Regret, Equal Likelyhood, } \\
\text { EOL, EV }\end{array}$ \\
\hline 6 & $\begin{array}{l}\text { Hasil } \\
\text { Keputusan }\end{array}$ & $\begin{array}{l}\text { Ukuran Akurasi Hasil } \\
\text { Keputusan }\end{array}$ & Nilai EV tertinggi \\
\hline
\end{tabular}

Sumber: Data yang diolah penulis (2018)

Teknik analisis

Metode Forecasting

a. Exponential Smoothing merupakan metodel peramalan rata-rata bergerak dengan pembobotan yang canggih, namun masih mudah digunakan. Metode ini menggunakan sedikit pencatatan data masa lalu.

b. Moving Average menggunakan sejumlah data aktual masa lalu untuk menghasilkan peramalan. Rata-rata bergerak berguna jika dapat mengasumsikan bahwa permintaan pasar akan stabil sepanjang masa yang kita ramalkan.

c. Trend projection yaitu metode peramalan yang menyesuaikan garis kecenderungan dengan rangkaian poin data historis dan kemudian memproyeksikan kemiringan garis kedalam peramalan masa yang akan datang, dalam jangka menengah maupun jangka panjang.

d. Decomposition Techniques adalah suatu prosedur dalam menganalisa data serial waktu dengan cara mengidentifikasi faktor-faktor komponen yang ada dalam suatu periode data. (Metode Additive Decomposition, Multiplicative Decomposition, Additive Decomposition Average All Additive Decomposition - Centered Moving AverageMultiplicative Decomposition Average All

Decision tree

a. Kriteria Maximax

b. Kriteria Minimax

c. Kriteria Maximax Regret

d. Kriteria Expected Value

e. Kriteria Expected Opportunity Loss

f. Penyusunan Pohon Keputusan 


\section{HASIL DAN PEMBAHASAN}

PT HIS Tour \& Travel adalah perusahaan yang bergerak dalam bidang jasa yang menyediakan berbagai jasa perjalanan wisata dan salah satunya adalah menyediakan tiket pesawat. Dalam penelitian ini penulis mengambil objek penelitian tentang penjualan tiket pesawat pada PT HIS Sari Tour\&Travel Cabang MM 2100 Cibitung

Tabel 4. Data Penjualan Tiket Pesawat tahun 2017-2018

\begin{tabular}{clrrlr}
\hline No & \multicolumn{1}{c}{ Bulan } & Penjualan & No & \multicolumn{1}{c}{ Bulan } & Penjualan \\
\hline $\mathbf{1}$ & Januari-17 & 511 & 13 & Januari-18 & 1019 \\
$\mathbf{2}$ & Februari & 610 & 14 & Februari & 1167 \\
$\mathbf{3}$ & Maret & 568 & 15 & Maret & 1063 \\
$\mathbf{4}$ & April & 585 & 16 & April & 1130 \\
$\mathbf{5}$ & Mei & 635 & 17 & Mei & 1102 \\
$\mathbf{6}$ & Juni & 378 & 18 & Juni & 516 \\
$\mathbf{7}$ & Juli & 603 & 19 & Juli & 1267 \\
$\mathbf{8}$ & Agustus & 638 & 20 & Agustus & 1360 \\
$\mathbf{9}$ & September & 611 & 21 & September & 1369 \\
$\mathbf{1 0}$ & Oktober & 829 & & & \\
$\mathbf{1 1}$ & November & 900 & & & \\
$\mathbf{1 2}$ & Desember & 907 & & & \\
\hline
\end{tabular}

Sumber: PT HISTour\&Travel (2018)

Tabel 5. Rekapitulasi Hasil Hitung Manual

\begin{tabular}{lrrr}
\hline \multicolumn{1}{c}{ Metode } & \multicolumn{1}{c}{ MAD } & \multicolumn{1}{c}{ MSE } & Forecast \\
\hline Exponential Smoothing & 187,60 & $53.988,59$ & 1332 \\
Moving Average & 159,50 & $48.589,73$ & 1332 \\
Trend Projection & 119,98 & $30.889,90$ & 1293 \\
Addictive Decomposition Average All & 116,48 & $25.127,00$ & 1296 \\
Addictive Decomposition CMA & $\mathbf{1 0 8 , 4 8}$ & $\mathbf{2 5 . 1 2 0 , 7 0}$ & $\mathbf{1 3 5 0}$ \\
Multiplicative Decomposition Average All & 121,10 & $28.343,40$ & 1294 \\
Multiplicative Decomposition CMA & 113,60 & $33.887,40$ & 1294 \\
\hline
\end{tabular}

Sumber: data yang diolah penulis (2018)

Dari hasil hitung peramalan secara manual dapat dilihat bahwa MAD dan MSE terkecil terdapat pada metode Addictive Decomposition CMA yaitu sebesar 108,48 dan 25.120,70

Tabel 6. Rekapitulasi Hasil Hitung Dengan QM For Windows

\begin{tabular}{lrrr}
\hline \multicolumn{1}{c}{ Metode } & \multicolumn{1}{c}{ MAD } & \multicolumn{1}{c}{ MSE } & Forecast \\
\hline Exponential Smoothing & 140,85 & $52.226,53$ & 1366 \\
Moving Average & 177,2 & $54.010,00$ & 1332 \\
Trend Projection & 114,26 & $29.393,04$ & 1293 \\
Addictive Decomposition Average All & 110,47 & $23.912,00$ & 1303 \\
Addictive Decomposition CMA & $\mathbf{1 0 4 , 7 6}$ & $\mathbf{2 2 . 8 9 7 , 5 7}$ & $\mathbf{1 3 7 1}$ \\
Multiplicative Decomposition Average All & 110,08 & $27.714,21$ & 1316 \\
Multiplicative Decomposition CMA & 112,26 & $27.690,80$ & 1412 \\
\hline
\end{tabular}

Sumber: data yang diolah penulis (2018)

Dari hasil hitung peramalan dengan QM For Windows dapat dilihat bahwa MAD dan MSE terkecil terdapat pada metode Addictive Decomposition CMA yaitu sebesar 104,476 dan 22.897,57 dengan hasil peramalan untuk periode selanjutnya adalah 1371. 
Decision Tree

Metode Decision Tree disini digunakan untuk analisi pembukaan cabang baru.

Tabel 7. Rincian Biaya Pembukaan cabang Masing-Masing Kota (dalam Rupiah)

Kota

\begin{tabular}{lrrr}
\cline { 2 - 4 } & $\begin{array}{c}\text { MEMBURUK } \\
(\text { Prob }=\mathbf{0 , 3 2})\end{array}$ & \multicolumn{1}{c}{$\begin{array}{c}\text { STABIL } \\
\text { (Prob }=\mathbf{0 , 4 8 )}\end{array}$} & \multicolumn{1}{c}{$\begin{array}{c}\text { MEMBAIK } \\
\text { (Prob = 0,20) }\end{array}$} \\
\hline Bekasi & $\mathbf{2 7 6 . 0 0 0 . 0 0 0}$ & $\mathbf{2 9 8 . 0 0 0 . 0 0 0}$ & $\mathbf{2 4 6 . 0 0 0 . 0 0 0}$ \\
Karawang & 220.000 .000 & 230.000 .000 & 214.000 .000 \\
Depok & 231.000 .000 & 236.000 .000 & 247.000 .000 \\
Bogor & 218.000 .000 & 241.000 .000 & 220.000 .000 \\
\hline
\end{tabular}

Sumber: PT HIS(2018)

Tabel di atas menjelaskan tentang 3 kondisi yang terjadi pada setiap kotanya, dimana masing-masing kondisi memiliki probabilitas atau peluang terjadinya kondisi yang berbeda.

Kriteria Maximax

Tabel 8. Kriteria Maximax

\begin{tabular}{lr}
\hline \multicolumn{1}{c}{ Keputusan } & Hasil Pertukaran \\
\hline Bekasi & Rp 298.000.000 \\
Karawang & Rp 230.000.000 \\
Depok & Rp 236.000.000 \\
Bogor & Rp 241.000.000 \\
\hline Sumber:
\end{tabular}

Sumber: Data yang diolah penulis (2018)

Kriteria Maximax mengambil kondisi tetinggi dari setiap kota. Dari tabel dilihat bahwa kondisi tertinggi berada di Bekasi yaitu sebesar Rp 298.000.000.

Kriteria Maximin

Tabel 9. Kriteria Maximin

\begin{tabular}{lr}
\hline \multicolumn{1}{c}{ Keputusan } & Pay-Off Minimum \\
\hline Bekasi & Rp276.000.000 \\
Karawang & Rp 214.000.000 \\
Depok & Rp 247.000 .000 \\
Bogor & Rp 218.000.000 \\
\hline
\end{tabular}

Sumber: Data yang diolah penulis (2018)

Kriteria Maximin mengambil keputusan terkecil dari setiap kondisi masing-masing kota. Dari tabel diatas dapat dilihat kondisi minimum yang tertinggi berada di Bekasi yaitu sebesar Rp276.000.000.

Kriteria Maximax Regret

Tabel 10. Kriteria Maximax Regret

\begin{tabular}{lr}
\hline \multicolumn{1}{c}{ Keputusan } & Pay-Off Minimum \\
\hline Bekasi & Rp 1.000.000 \\
Karawang & Rp 68.000 .000 \\
Depok & Rp 62.000 .000 \\
Bogor & Rp 58.000 .000 \\
\hline \multicolumn{2}{l}{ Sumber: Data yang diolah penulis (2018) }
\end{tabular}


Cara menghitung tabel diatas :

Kondisi memburuk :
Bekasi
: Rp 276.000.000 - Rp 276.000.000 =0
Karawang $\quad:$ Rp 276.000.000 - Rp 220.000.000 =Rp 56.000.000
Depok $\quad:$ Rp 276.000.000 - Rp 231.000.000 =Rp 45.000.000
Bogor $\quad:$ Rp 276.000.000 - Rp 218.000.000=Rp 58.000.000
Kondisi stabil :
Bekasi $\quad$ : Rp 298.000.000 - Rp 298.000.000 =0
Karawang $\quad:$ Rp 298.000.000 - Rp 230.000.000 =Rp 68.000.000
Depok $\quad:$ Rp 298.000.000 - Rp 236.000.000 =Rp 62.000.000
Bogor $\quad:$ Rp 298.000.000 - Rp 241.000.000 =Rp 57.000.000
Kondisi membaik :
$\begin{array}{ll}\text { Bekasi } & : \text { Rp 247.000.000 - Rp 246.000.000 }=\text { Rp 1.000.000 } \\ \text { Karawang } & : \text { Rp 247.000.000 - Rp 214.000.000 =Rp 33.000.000 } \\ \text { Depok } & : \text { Rp 247.000.000 - Rp 247.000.000 =0 } \\ \text { Bogor } & : \text { Rp 247.000.000 - Rp 220.000.000 =Rp 27.000.000 }\end{array}$

Kemudian dari 3 kondisi masing-masing kota diambil nilai tertinggi, maka itulah hasil Maximax Regret-nya setelah itu diantara masing-masing kota dipilih yang memiliki nilai terendah , maka itu adalah hasil keputusannya. Dari tabel 10 dapat kondisi terkecil berada di Kota Bekasi yaitu Rp 1.000.000, maka keputusannya adalah Kota Bekasi

Kriteria Equal Likelihood

Tabel 11. Kriteria Equal Likelihood

\begin{tabular}{ll}
\hline Keputusan & Perhitungan \\
\hline Bekasi & $\mathbf{2 7 6 . 0 0 0 . 0 0 0}(\mathbf{0 , 3 3})+\mathbf{2 9 8 . 0 0 0 . 0 0 0}(\mathbf{0 , 3 3})+\mathbf{2 4 6 . 0 0 0 . 0 0 0}(\mathbf{0 , 3 3}) \mathbf{= 2 5 4 . 2 8 0 . 0 0 0}$ \\
Karawang & $220.000 .000(0,33)+230.000 .000(0,33)+214.000 .000(0,33)=205.800 .000$ \\
Depok & $231.000 .000(0,33)+236.000 .000(0,33)+247.000 .000(0,33)=214.200 .000$ \\
Bogor & $218.000 .000(0,33)+241.000 .000(0,33)+220.000 .000(0,33)=203.700 .000$ \\
\hline
\end{tabular}

Sumber: Data yang diolah penulis (2018)

Equal Likelihood diambil dari setiap kondisi yang dikalikan 0,33 dan diambil hasil tertinggi dari kotakota tersebut. Dari perhitungan pada tabel diatas dapat dilihat hasil tertinggi berada di Bekasi yaitu Rp 254.280.000.

Expected Opportunity Loss (EOL).

Tabel 12. Hasil PenguranganPay-Off

\begin{tabular}{lrrr}
\hline \multirow{1}{*}{ Kota } & \multicolumn{3}{c}{ KondisiEkonomiPolitik } \\
\cline { 2 - 4 } & $\begin{array}{r}\text { MEMBURUK } \\
\text { (Prob = 0,32) }\end{array}$ & $\begin{array}{c}\text { STABIL } \\
\text { (Prob = 0,48) }\end{array}$ & $\begin{array}{c}\text { MEMBAIK } \\
\text { (Prob= 0,20) }\end{array}$ \\
\hline Bekasi & $\mathbf{0}$ & $\mathbf{0}$ & $\mathbf{1 . 0 0 0 . 0 0 0}$ \\
Karawang & 56.000 .000 & 68.000 .000 & 33.000 .000 \\
Depok & 45.000 .000 & 62.000 .000 & 0 \\
Bogor & 58.000 .000 & 57.000 .000 & 27.000 .000 \\
\hline
\end{tabular}

Sumber: Data yang diolah penulis (2018)

Tabel diatas adalah hasil pengurangan pay-off masing-masing kondisi yaitu pay-off tertinggi dikurangi pay-off setiap kota. Hasil diatas akan digunakan untuk menghitungExpected Opportunity Loss (EOL). 
Cara menghitung tabel diatas :

Kondisi memburuk :

\begin{tabular}{|c|c|}
\hline Bekasi & $: \operatorname{Rp} 276.000 .000-\operatorname{Rp} 276.000 .000=0$ \\
\hline Karawang & $: \operatorname{Rp} 276.000 .000-\operatorname{Rp} 220.000 .000=\operatorname{Rp} 56.000 .000$ \\
\hline Depok & : Rp 276.000.000 - Rp 231.000.000 =Rp 45.000.000 \\
\hline Bogor & $: \operatorname{Rp} 276.000 .000-\operatorname{Rp} 218.000 .000=\operatorname{Rp} 58.000 .000$ \\
\hline \multicolumn{2}{|c|}{ Kondisi stabil : } \\
\hline Bekasi & : Rp 298.000.000 - Rp 298.000.000 =0 \\
\hline Karawang & $: \operatorname{Rp} 298.000 .000-\operatorname{Rp} 230.000 .000=\operatorname{Rp} 68.000 .000$ \\
\hline Depok & $: \mathrm{Rp} 298.000 .000-\mathrm{Rp} 236.000 .000=\mathrm{Rp} 62.000 .000$ \\
\hline Bogor & $: \operatorname{Rp} 298.000 .000-\operatorname{Rp} 241.000 .000=\operatorname{Rp} 57.000 .000$ \\
\hline \multicolumn{2}{|c|}{ Kondisi membaik : } \\
\hline Bekasi & : Rp 247.000.000 - Rp 246.000.000 = Rp 1.000.000 \\
\hline Karawang & $: \operatorname{Rp} 247.000 .000-\operatorname{Rp} 214.000 .000=\operatorname{Rp} 33.000 .000$ \\
\hline Depok & $: \mathrm{Rp} 247.000 .000-\mathrm{Rp} 247.000 .000=0$ \\
\hline Bogor & : Rp 247.000.000 - Rp 220.000.000 =Rp 27.000.000 \\
\hline
\end{tabular}

Tabel 13. Expected Opportunity Loss (EOL)- dalam Rupiah

\begin{tabular}{|c|c|}
\hline Keputusan & Perhitungan \\
\hline Bekasi & $0(0,32)+0(0,48)+1.000 .000(0,20)=1.000 .000$ \\
\hline Karawang & $56.000 .000(0,32)+62.000 .000(0,48)+33.000 .000(0,20)=54.280 .000$ \\
\hline Depok & $45.000 .000(0,32)+62.000 .000(0,48)+0(0,20)=44.160 .000$ \\
\hline Bogor & $58.000 .000(0,32)+57.000 .000(0,48)+27.000 .000(0,20)=51.320 .000$ \\
\hline
\end{tabular}

Sumber: Data yang diolah penulis (2018)

Expected Opportunity Loss (EOL) diperoleh dari hasil tabel diatas dengan masing-masing probabilitas setiap kondisi lalu diambil nilai terkecil. Dari tabel tersebut dapat dilihat bahwa hasil terkecil adalah Bekasi yaitu Rp 1.000.000.

Kriteria Expected Value (EV)

Tabel 14. Kriteria Expected Value (EV) - dalam Rupiah

\begin{tabular}{|c|c|}
\hline Keputusan & Perhitungan \\
\hline Bekasi & $276.000 .000(0,32)+298.000 .000(0,48)+(246.000 .000(0,20)=280.560 .000$ \\
\hline Karawang & $220.000 .000(0,32)+230.000 .000(0,48)+214.000 .000(0,20)=223.600 .000$ \\
\hline Depok & $231.000 .000(0,32)+236.000 .000(0,48)+247.000 .000(0,20)=236.600 .000$ \\
\hline Bogor & $218.000 .000(0,32)+241.000 .000(0,48)+220.000 .000(0,20)=229.440 .000$ \\
\hline
\end{tabular}

Sumber: Data yang diolah penulis (2018)

Expected Value (EV) diperoleh dari perkalian setiap kondisi dengan masing-masing probabilitasnya lalu diambil hasil tertinggi. Dari tabel diatas dapat dilihat bahwa hasil tertinggi berada di Bekasi yaitu Rp 280.560.000.

Menurut Djie (2013:113-119) perusahaan harus memilih pilihan yang memiliki nilai expected value yang paling tinggi karena akan menghasilkan keuntungan yang tinggi juga. Semua kriteria menunjukakan bahwa Bekasi adalah pilihan yang paling tepat. Pohon keputusan dapat digambarkan ketika sudah mendapatkan hasil dari expected value. Pohon keputusan diatas menjelaskan bahwa dari keempat keputusan pembukaan cabang untuk PT Harum Indah Sari dibagi ke empat kota yaitu Bekasi, Karawang, Depok, dam Bogor. Perhitungannya telah dijelaskan perhitungan sebelumnya, setelah dilihat dan dimasukkan kedalan pohon keputusan maka mendapatkan bentuk pohon keputusan seperti diatas. Menurut pohon keputusan diatas keputusan terbaik dalam kasus ini adalah 
pembukaan cabang di Kota Bekasi yang memliki nilai tertinggi yaitu Rp 280.680.000, dengan kondisi stabil sebesar Rp 230.000.000.

\section{KESIMPULAN}

Berdasarkan hasil penelitian, maka dapat ditarik beberapa simpulan sebagai berikut:

1. Melalui perhitungan peramalan (forecasting) secara manual dapat diketahui bahwa metode peramalan terbaik adalah menggunakan metode Addictive Decomposition CMA dengan tingkat kesalahan atau hasi MAD dan MSE terkecil dibanding dengan metode lain yaitu 108,48 dan 25.120,70 dengan hasil peramalan sebesar 1350

2. Melalui perhitungan peramalan (forecasting) dengan menggunakan aplikasi QM for Windows dapat diketahui bahwa peramalan terbaik adalah menggunakan metode Addictive Decomposition CMA dengan tingkat kesalahan atau hasi MAD dan MSE terkecil dibanding dengan metode lain yaitu: 104,76 dan 22.897,57 dan hasil peramalan sebesar 1371.

3. Melalui perhitungan dan penyusunanan pohon keputusan (Decision tree) secara manual dapat diketahui bahwa kota Bekasi adalah keputusan yang paling tepat diantara alternatif yang lain dengan hasil $\mathrm{Rp} 280.560 .000$

4. Melalui perhitungan dan penyusunanan pohon keputusan (Decision tree) dengan menggunakan aplikasi QM for Windows dapat diketahui bahwa hasil maximin dan maximax untuk kasus ini ditunjukan pada kota Bekasi yaitu sebesar Rp 246.000.000 dan Rp 299,000.000.

5. Beradasarkan hasil forecasting dan decision tree maka dapat disimpulkan bahwa peluang peningkatan penjualan tiket pesawat untuk PT Harum Indah Sari Tour\& Travel Cabang Mm2100 Cibitung akan mengalami kenaikan dan lokasi paling tepat untuk permasalahan pembukaan cabang adalah kota Bekasi.

Implikasi teoritis

1. Hasil perhitungan peramalan (forecasting) menunjukka bahwa terjadi peningkatan penjualan untuk periode mendatang yaitu dari 1139 menjadi 1371. Hal tersebut menunjukan bahwa prospek penjualan tiket pesawat untuk kedepannya memiliki peluang yang baik.

2. Hasil dari perhitungan pohon keputusan (Decision Tree) menunjukkan bahwa kota Bekasi adalah keputusan terbaik untuk melakukan pembukaan cabang dari PT Harum Indah Sari. Selain ditunjukkan dengan hasil dari pohon keputusan berikut adalah data pendukung yang menunjukkan bahwa kota Bekasi adalah daerah potensial untuk melakukan pembukaan cabang:

- Kota Bekasi memiliki jumlah penduduk yang memiliki peningkatan yang baik setiap tahunnya seperti yang penulis uraikan pada pembahasan sebelunya.

- Jumlah penduduk produktif (bekerja) mencapai 80\% dari jumlah penduduk yang ada.

- Kota Bekasi memiliki laju Pertumbuhan Ekonomi yang baik, seperti kenaikan pada tahun 2015 ke 2016 yaitu 5,57\% menjadi 5,82\%.

- Kota Bekasi memiliki Produk Domestik Regional Bruto (PDRB) yang memiliki peningkatan yang baik bahkan lebih tinggi dari pada kota lain seperti Depok. Untuk tahun 2015 Bekasi meimiliki kenaikan sebesar 3\% dari tahun sebelunya sedangkan depok hanya memiliki kenaikan sebesar $1 \%$ dibanding dengan tahun sebelumnya.

Implikasi praktis

- Wawancara terhadap pemilik cabang

Dalam hal ini peneliti melakukan wawancara dan diskusi dengan kepala cabang dari PT Harum Indah sari Tour \& Travel. Peneliti menunjukkan hasil perhitungan forecasting dan decision tree yang telah peneliti hitung, selain itu peneliti juga menunjukan alasan-alasan mengenai kota Bekasi adalah daerah potensial untuk pembukaan cabang baru seperti yang peneliti uraikan pada pembahasan sebelumnya. Dalam hal ini kepala cabang setuju dan membenarkan hasil 
penelitian peneliti, hasil ini akan diajukan ke bagian pusat karena segala keputusan harus dialporkan ke perusahaan pusat terlebih dahulu.

- Wawancara terhadap pemilik travel lain (PT Surya Mandala Travel Cikarang Barat Bekasi)

Selain melakukan wawancara terhadap pemilik cabang peneliti juga melakukan wawancara kepada pemilik cabang tour \& travel lain. Dalam wawancara tersebut peneliti menanyakan pendapat mengenai usaha travel khususnya penjualan tiket pesawat dan apakah pembukaan usaha travel dibekasi memiliki prospek yaang bagus. Narasumber menjelaskan bahwa usaha travel khususnya penjualan tiket pesawat memiliki peluang yang cukup baik di era modern seperti ini. Banyak orang yang cenderung memilih pesawat sebagai alat transportasi yang praktis dan cepat, akan tetapi narasumber mengatakan bahwa Bekasi kurang memiliki prospek yang baik dalan penjualan tiket pesawat. Narasumber menyarankan Kota Jakarta dan Tanggerang lebih memiliki prospek yang baik dalam bidang usaha ini.

- Ruko yang direncanakan untuk disewa beralamat di jalan Bulevar Selatan, Marga Mulya Bekasi Jawa Barat.

- Wawancara dengan beberapa pedagang dan karyawan disekitar ruko

Menurut beberapa pedagang dan karyawan, ada yang mengatakan setuju dan ada yang tidak setuju. Narasumber pertama mengatakan bahwa pemilihan lokasi ini sangat tepat karena berdekatan dengan Mall Sumarecon Bekasi. Narasumber kedua tidak setuju karena disekitar situ tidak ada agen penjual tiket pesawat jadi banyak orang tidak mengetahui kalau ada agen penjualan tiket didaerah ini. Narasumber terakhir setuju karena daerah ini termasuk daerah yang strategis dan ramai dikunjungi.

Saran

Berdasarkan hasil penelitian, pembahasan dan simpulan yang telah disajikan, berikut adalah beberapa saran yang diharapkan membangun dan dapat dijadikan pertimbangan untuk PT. HIS Tour \& Travel Cabang MM2100 Cibitung:

1. Melihat prospek penjualan yang baik perusahaan harus senantiasa mengimbangi dengan pelayanan yang baik terhadap pelanggan, supaya pelanggan merasa puas dan senang telah menggunakan jasa perusahaan.

2. Perusahaan sebaiknya memberikan servive excelent kepada semua pelanggan, karena hal tersebut akan menjadikan pelanggan loayal dan akan menggunakan jasa perusahaan terus menerus.

3. Untuk awal penjualan di cabang baru sebaiknya perusahaan menawarkan promo-promo dan potongan harga untuk awal pembelian, supaya dapat menarik minat konsumen lebih cepat.

4. Untuk pembukaan cabang baru sebaiknya dikelola dengan lebih baik mulai dari team work karyawan hingga servive-service yang diberikan kepada pelanggan, supaya cabang baru ini cepat berkembang dan memiliki pelanggan yang setia.

\section{REFERENSI}

Alma, B. (2016). Manajemen Pemasaran dan Pemasaran Jasa, Alfabeta, Bandung.

Assauri, S. (2018). Manajemen Bisnis Pemasaran, Raja Grafindo Persada, Depok.

Chaniago, A. (2017). Teknik Pengambilan Keputusan (Pendekatan Teori \& Studi Kasus) Cetakan 1, Lentera Ilmu Cendekia, Jakarta. Bandung.

Djie, I.S.J (2013). Analisis Peramalan Penjualan dan Pengggunaan Metode Linear Programming dan Decision Tree Guna Mengoptimalkan Keuntungan pada PT Primajaya Pantes Garment. Jurnal The Winners 14 (2): 71-142, Perpustakaan UMB, Jakarta.

Handayani, R dkk. (2015). Analisa Peramalan Kebutuhan Persediaan untuk Keunggulan Bersaing pada Perusahaan ORCHA. Jurnal Manajemen 5 (2): 93-101, Universitas Telkom, Bandung.

Handoko, T. H. (2013). Manajemen Edisi 2. Yogyakarta: BPFE. 
Heizer, J dan Render, B. (2015). Manajemen Operasi: Manajemen Keberlangsungan dan Rantai Pasokan,Edisi 11, Jakarta: Salemba.

Irmawati. (2015). Manajemen Pemasaran di Rumah Sakit, Institut Ilmu Kesehatan, University Press. Ismainar, H. (2018). Manajemen Unit Kerja. Yogyakarta : Deepublish.

Karyoto. (2016). Dasar-dasar manajemen: Teori, Definisi dan Konsep. Jakarta: Andi Publiser.

Marsetiani, M. (2014). Model Optimasi Penentuan Kombinasi Produk Menggunakan Metode Linear Programming pada perusahaan Bidang Fashion. Jurnal The Winners 15 (1): 1-84.

Martono, N. (2016). Metode Penelitian Kuantitatif: Analisa isi dan Analisa Data Sekunder, Jakarta: Raja Grafindo Prasada

Nasehudin, T. S dan Gozali, N. (2012). Metode Penelitian Kuantitatif, Bandung : Pustaka Setia

Prasetya, H dan Lukiastiti, F. (2013). Manajemen Operasi, Yogyakarta : Azza Grafika

Rusdiana, H.A. (2014). Manajemen Operasi, Bandung: Pustaka Setia.

Sarjono, H dan Abbas, B. S. (2017). Forecasting: Aplikasi Penelitian Qm For Windows vs MINITAB vs MANUAL,Edisi Pertama, Jakarta: Mitra Wacana Media

Selang, A.D Christian. (2013). Bauran Pemasaran (Marketing mix) Pengaruhnya Terhadap Loyalitas Konsumen pada Fresh Mart Bahu Mall Manado. Jurnal EMBA 1 (3): 71-80 (melalui) http:// media.neliti.com (06 Desember 2018)

Subagyo, J. (2015). Metode Penelitian dalam Teori dan Praktek, Jakarta: Rineka Cipta.

Sugiarto, E. (2015). Menyusun Proposal Penelitian Kualitatif Skripsi dan Tesis, Yogyakarta: Suaka Pustaka,.

Suryani, T. (2017). Manajemen Strategik Bank di Era Global. Jakarta: Prenamedia Group,

Usman, W. (2014). Metode Kuantitatif,Edisi 1 Modul 1-9, Universitas Terbuka, Tanggerang.

Utama, I Gusti Bagus Rai. (2017). Pemasaran Pariwiata, Edisi 1, Yogyakarta.

Yusuf, M. (2014). Metode Penelitian : Kuantitatif dan Penelitian Gabungan Edisi Pertama, Jakarta: Kencana

www.bps.go.id (11 Juli 2018)

www.bkpm.go.id ( 3 Agustus 2018)

www.gobekasi.co.id (10 Agustus 2018)

www.merdeka.com ( 10 Agustus 2018)

www.tribunnews.com (10 Agustus 2018)

Majalan SWA (10 Agustus-16 Agustus 2018)

\section{PROFIL PENULIS}

Sofiyatun adalah mahasiswi Sekolah Tinggi Ilmu Ekonomi Bisnis Indonesia dengan jurusan Manajemen. Peneliti memiliki ketertarikan terhadap dunia pemasaran khususnya pemasaran jasa dan dalam penelitian ini penulis memilih jasa penjualan tiket pesawat untuk melakukan penelitian.

Haryadi Sarjono adalah dosen Jurusan Manajemen, Universitas Bina Nusantara, Jakarta Barat, yang memiliki ketertarikan terhadap ilmu Manajemen Operasional dan Teknik Riset Operasi. 